\title{
The Migration Rule of Pb Content Transported from Different Sources
}

\author{
Dongfang Yang1,2,3, Danfeng Yang ${ }^{4}$ \\ ${ }^{1}$ Research Center for Karst Wetland Ecology, Guizhou Minzu University, Guiyang, China \\ ${ }^{2}$ College of Chemistry and Environmental Science, Guizhou Minzu University, Guiyang, China \\ ${ }^{3}$ North China Sea Environmental Monitoring Center, SOA, Qingdao, China \\ ${ }^{4}$ The Fu Foundation School of Engineering and Applied Science, Columbia University, New York, USA \\ Email: dfyang_dfyang@126.com
}

How to cite this paper: Yang, D. F., \& Yang, D. F. (2021). The Migration Rule of $\mathrm{Pb}$ Content Transported from Different Sources. Journal of Geoscience and Environment Protection, 9, 165-175.

https://doi.org/10.4236/gep.2021.95012

Received: May 10, 2021

Accepted: May 28, 2021

Published: May 31, 2021

\begin{abstract}
According to the survey materials of the waters of Jiaozhou Bay in May, September and October 1993, this article studied the content of $\mathrm{Pb}$ and its horizontal distribution in the surface water bodies. The results showed that the $\mathrm{Pb}$ content in the waters of Jiaozhou Bay ranged within $0.62-3.05 \mu \mathrm{g} / \mathrm{L}$, which conformed to the seawater standard of Class I and II. And it also indicated that in terms of the $\mathrm{Pb}$ content, the water bodies of Jiaozhou bay were mildly contaminated by $\mathrm{Pb}$ content in May, September and October. The $\mathrm{Pb}$ content in Jiaozhou bay mainly had three sources, the transportation of rivers, surface runoff and offshore ocean currents. The $\mathrm{Pb}$ content was $2.13 \mu \mathrm{g} / \mathrm{L}$ transported from the rivers, $2.74 \mu \mathrm{g} / \mathrm{L}$ from the surface runoff and $3.05 \mu \mathrm{g} / \mathrm{L}$ from the offshore ocean currents. It demonstrated that the transportation of rivers, surface runoff and offshore ocean currents had been moderated polluted by $\mathrm{Pb}$ content. Three different migration paths of $\mathrm{Pb}$ content, from land, ocean to Jiaozhou Bay water bodies, have been expressed in model block diagram. In the migration process of $\mathrm{Pb}$ content transported from different sources, the author found out the migration rules: 1 ) the $\mathrm{Pb}$ content was continuously decreased with the extension of migration distance; 2) the $\mathrm{Pb}$ content in the ocean water body was very high with the accumulation of $\mathrm{Pb}$ content in the ocean.
\end{abstract}

\section{Keywords}

$\mathrm{Pb}$ Content, Sources, Process, Rules, Jiaozhou Bay

\section{Introduction}

Humans continually emit $\mathrm{Pb}$ content to land, ocean and atmosphere which 
brings the $\mathrm{Pb}$ pollution to global environment and ecology. The $\mathrm{Pb}$ content is transported to the ocean and is gradually accumulated in the ocean in the final (Yang, Su, \& Gao, 2008; Yang, Guo, Zhang, Ding, \& Bu, 2011; Yang, Zhu, Wang, He, \& Yang, 2014; Yang, Geng, Chen, Xu, \& Cui, 2014; Yang, Ge, Sun, Li, \& Yang, 2014; Yang, Zhu, Wang, Yang, \& Wu, 2014). Therefore, the pollution degree, sources of pollution, and the migration process of $\mathrm{Pb}$ content in the coastal waters have attracted much attention. Based on the survey data in 1993, this article discussed the $\mathrm{Pb}$ content, horizontal distribution, and its sources in the waters of Jiaozhou Bay, and determined the water quality, sources background, volume of sources, and migration paths and process, providing scientific and theoretical basis for the study of sources of $\mathrm{Pb}$, pollution degree and migration process.

\section{Survey Waters, Materials and Methods}

\subsection{Natural Environment of Jiaozhou Bay}

Jiaozhou Bay is located in the southern part of Shandong Peninsula. Its geographical position is between $120^{\circ} 04^{\prime} \mathrm{E}-120^{\circ} 23^{\prime} \mathrm{E}$ and $35^{\circ} 58^{\prime} \mathrm{N}-36^{\circ} 18^{\prime} \mathrm{N}$. It is bounded by the line connecting Tuan Island and Xuejia Island, and is connected to the Yellow Sea. With an area of about $446 \mathrm{~km}^{2}$ and an average water depth of about $7 \mathrm{~m}$, it is a typical semi-enclosed bay. There are more than a dozen rivers entering the sea in Jiaozhou Bay, among which the Dagu River, Yang River and the Haibo River, Licun River and Loushan River in Qingdao City with larger runoff and sand content. These rivers are all seasonal rivers, and the river hydrological characteristics have obvious seasonal changes (Yang, Chen, \& Gao, 2005; Yang, Wang, \& Gao, 2004).

\subsection{Materials and Methods}

The survey data of Cd content in Jiaozhou Bay in May, September and October 1993 used in this study are provided by the North Sea Monitoring Center of the State Oceanic Administration. Seven stations were set up in the waters of Jiaozhou Bay to take water samples: stations H3101, H3102, H3103, H3104, H3105, H3106 and H3107 (Figure 1). Sampling was conducted three times in May, September and October 1993, respectively. Water samples were taken according to the water depth (surface and bottom layers were taken when the depth $>10 \mathrm{~m}$, and only the surface layer was taken when the depth $<10 \mathrm{~m}$ ) for investigation and sampling. The survey of PHC content in Jiaozhou Bay water body was carried out according to the national standard method, which was recorded in the national "Marine Monitoring Code" (SOA, 1991).

\section{Results}

\subsection{Pb Content}

The nation has put forward the national seawater standards of Class I (1.00 $\mu \mathrm{g} / \mathrm{L})$, Class I $(5.00 \mu \mathrm{g} / \mathrm{L})$, Class III $(10.00 \mu \mathrm{g} / \mathrm{L})$ and Class IV $(50.00 \mu \mathrm{g} / \mathrm{L})$. In May, September and October, the content of $\mathrm{Pb}$ in the waters of Jiaozhou Bay 


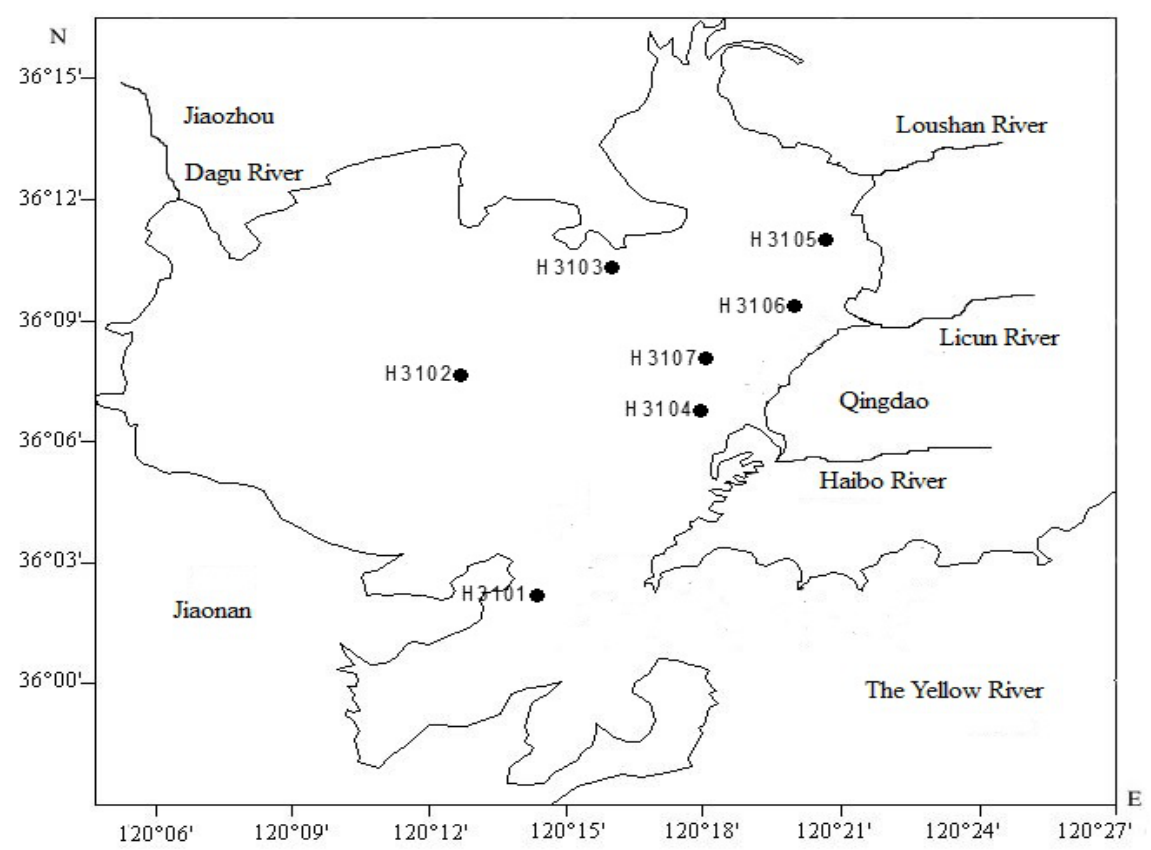

Figure 1. Investigation sites in Jiaozhou Bay.

ranged within $0.62-3.05 \mu \mathrm{g} / \mathrm{L}$, which met the seawater standards of Class I and II.

In May, the $\mathrm{Pb}$ content in the waters of Jiaozhou Bay ranged within $0.84-2.13$ $\mu \mathrm{g} / \mathrm{L}$ (Table 1). The high value area appeared in the estuary of nearshore waters of Haibo River, station H3104 and H3107, where the range of Pb content was $2.02-2.13 \mu \mathrm{g} / \mathrm{L}$ that met the national seawater standard of Class II $(5.00 \mu \mathrm{g} / \mathrm{L})$. The low value area appeared in the northern and northeastern waters of Jiaozhou Bay, station $\mathrm{H} 3103$ and $\mathrm{H} 3105$, where the range of $\mathrm{Pb}$ content was relatively low, $0.84-0.97 \mu \mathrm{g} / \mathrm{L}$, met the national seawater standard of Class I $(1.00 \mu \mathrm{g} / \mathrm{L})$. In other water areas of Jiaozhou Bay, the $\mathrm{Pb}$ content was relatively high, which exceeded the national seawater standard of Class I $(1.00 \mu \mathrm{g} / \mathrm{L})$ but lower than the national seawater standard of Class II $(5.00 \mu \mathrm{g} / \mathrm{L})$. In May, the Pb content in the entire waters of Jiaozhou Bay was relatively high, and the variation range of $\mathrm{Pb}$ content was $0.84-2.13 \mu \mathrm{g} / \mathrm{L}$, met the national seawater standards of Class I and Class II.

In September, the $\mathrm{Pb}$ content in the waters of Jiaozhou Bay ranged within 0.78 - $2.74 \mu \mathrm{g} / \mathrm{L}$ (Table 1). The high value area appeared in the northern nearshore waters and the central waters of Jiaozhou Bay, station H3103 and H3102, where the range of $\mathrm{Pb}$ content was $2.05-2.74 \mu \mathrm{g} / \mathrm{L}$ that met the national seawater standard of Class II $(5.00 \mu \mathrm{g} / \mathrm{L})$. The low value area appeared in the eastern waters of Jiaozhou Bay, station $\mathrm{H} 3104, \mathrm{H} 3107$ and $\mathrm{H} 3106$, where the range of $\mathrm{Pb}$ content was relatively low, $0.78-0.84 \mu \mathrm{g} / \mathrm{L}$, met the national seawater standard of Class I $(1.00 \mu \mathrm{g} / \mathrm{L})$. In other water areas of Jiaozhou Bay, the Pb content was relatively high, which exceeded the national seawater standard of Class I (1.00 $\mu \mathrm{g} / \mathrm{L})$ but lower than the national seawater standard of Class II $(5.00 \mu \mathrm{g} / \mathrm{L})$. In 
Table 1. The surface water quality in Jiaozhou bay in May, September and October.

\begin{tabular}{cccc}
\hline & May & September & October \\
\hline $\mathrm{Pb}$ content $/ \mu \mathrm{g} \cdot \mathrm{L}^{-1}$ in the seawater & $0.84-2.13$ & $0.78-2.74$ & $0.62-3.05$ \\
National Seawater Standards & Class I \& II & Class I \& II & Class I \& II \\
\hline
\end{tabular}

September, the $\mathrm{Pb}$ content in the entire waters of Jiaozhou Bay was relatively high, and the variation range of $\mathrm{Pb}$ content was $0.78-2.74 \mu \mathrm{g} / \mathrm{L}$, met the national seawater standards of Class I and Class II.

In October, the $\mathrm{Pb}$ content in the waters of Jiaozhou Bay ranged within 0.62 $3.05 \mu \mathrm{g} / \mathrm{L}$ (Table 1). The high value area appeared in the mouth waters of the bay, station $\mathrm{H} 3101$, where the highest value of $\mathrm{Pb}$ content was $3.05 \mu \mathrm{g} / \mathrm{L}$ that met the national seawater standard of Class II $(5.00 \mu \mathrm{g} / \mathrm{L})$. The low value area appeared in the northern waters of Jiaozhou Bay, station H3103, and H3105, where the range of $\mathrm{Pb}$ content was relatively low, $0.62-0.79 \mu \mathrm{g} / \mathrm{L}$, met the national seawater standard of Class I $(1.00 \mu \mathrm{g} / \mathrm{L})$. In other water areas of Jiaozhou Bay, the $\mathrm{Pb}$ content was relatively high, which exceeded the national seawater standard of Class I $(1.00 \mu \mathrm{g} / \mathrm{L})$ but lower than the national seawater standard of Class II $(5.00 \mu \mathrm{g} / \mathrm{L})$. In October, the $\mathrm{Pb}$ content in the entire waters of Jiaozhou Bay was relatively high, and the variation range of $\mathrm{Pb}$ content was $0.78-2.74 \mu \mathrm{g} / \mathrm{L}$, met the national seawater standards of Class I and Class II.

Therefore, the variation range of $\mathrm{Pb}$ content in the waters of Jiaozhou Bay was $0.62-3.05 \mu \mathrm{g} / \mathrm{L}$ in May, September and October, which met the seawater standards of Class II, III and IV. It indicated that the entire water body of Jiaozhou Bay was mildly polluted by $\mathrm{Pb}$ content (Table 1 ).

\subsection{Horizontal Distribution in the Surface Layer}

In May, in the estuary coastal waters of Haibo River, station $\mathrm{H} 3107$, the Pb content was the highest, $2.13 \mu \mathrm{g} / \mathrm{L}$. A high $\mathrm{Pb}$ content area was formed centered on the coastal waters of the estuary of Haibo River, and there appeared a series of semi-circles with different gradients. The $\mathrm{Pb}$ content decreased from the high content of $2.13 \mu \mathrm{g} / \mathrm{L}$ in the center to the surroundings along the gradient, to 0.97 $\mu \mathrm{g} / \mathrm{L}$ in the northeastern waters of the bay, to $0.84 \mu \mathrm{g} / \mathrm{L}$ in the northern waters of the bay, and to $1.14 \mu \mathrm{g} / \mathrm{L}$ in the central waters of the bay (Figure 2).

In September, in the northern waters of Jiaozhou bay, station H3103, the highest $\mathrm{Pb}$ content was $2.74 \mu \mathrm{g} / \mathrm{L}$. A high $\mathrm{Pb}$ content area was formed centered on the northern waters of the bay, forming a series of semi-circles with different gradients. The $\mathrm{Pb}$ content decreased from the high content of $2.74 \mu \mathrm{g} / \mathrm{L}$ in the center to the surroundings along the gradient, to $0.84 \mu \mathrm{g} / \mathrm{L}$ in the eastern waters of the bay, to $0.80 \mu \mathrm{g} / \mathrm{L}$ in the southeastern waters of the bay, and to $1.14 \mu \mathrm{g} / \mathrm{L}$ in the central waters of the bay (Figure 3).

In October, in the mouth waters of Jiaozhou bay, station H3101, the highest $\mathrm{Pb}$ content was $3.05 \mu \mathrm{g} / \mathrm{L}$. A high $\mathrm{Pb}$ content area was formed centered on the mouth waters of the bay, forming a series of semi-circles with different gradients. 


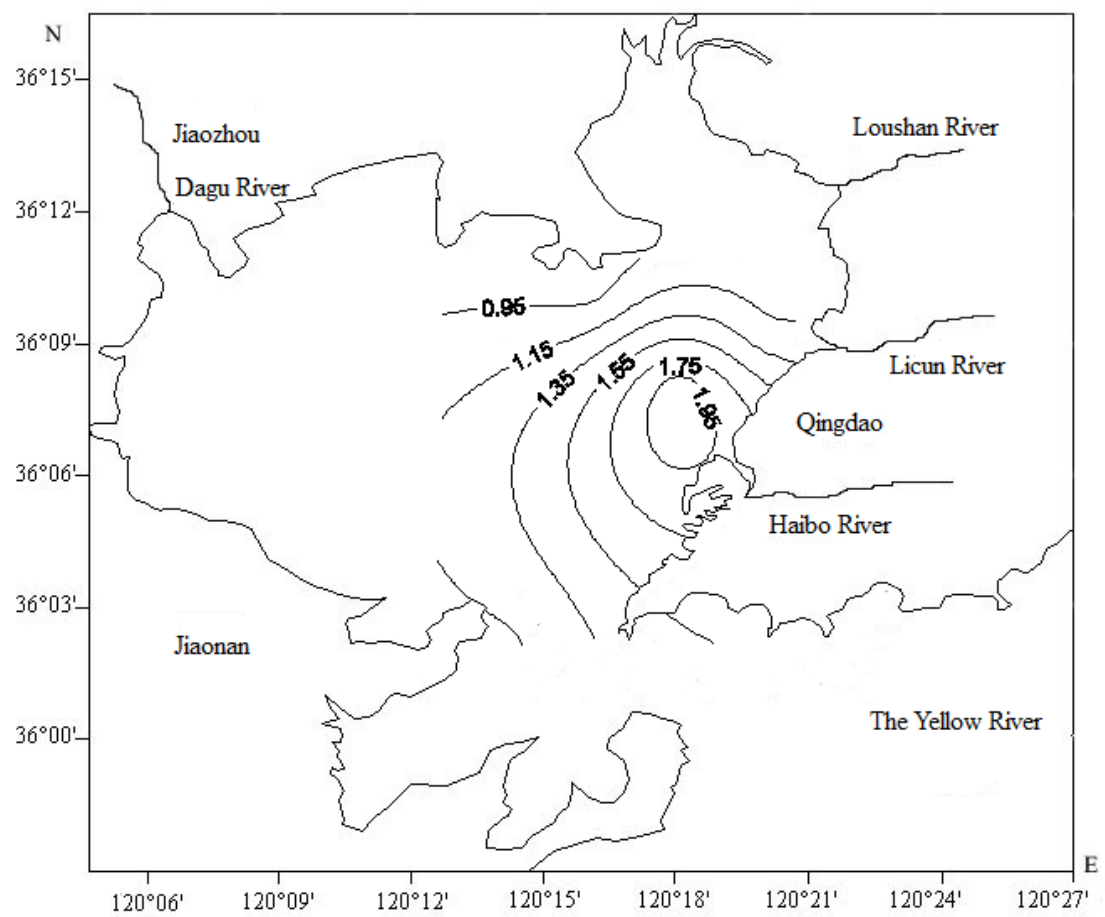

Figure 2. $\mathrm{Pb}$ content distribution at the surface in Jiaozhou Bay in May $(\mu \mathrm{g} / \mathrm{L})$.

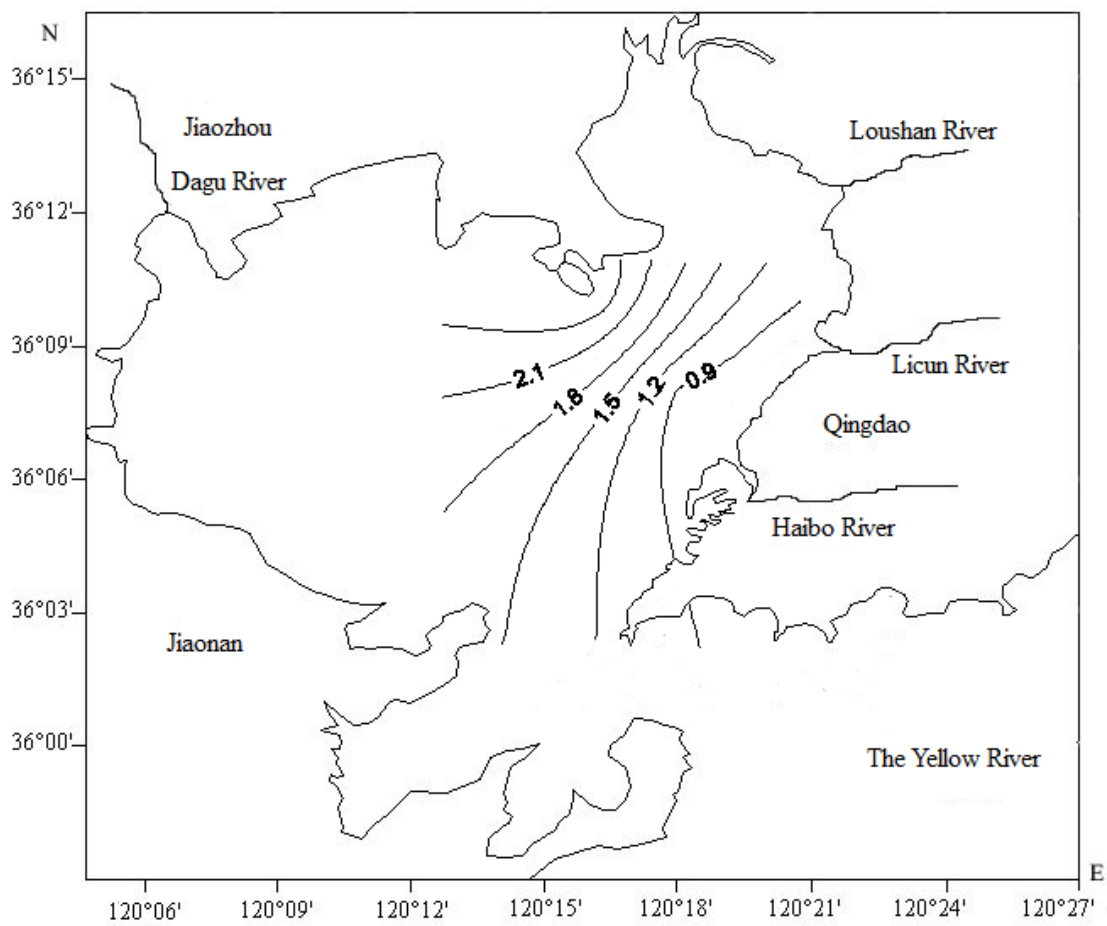

Figure 3. $\mathrm{Pb}$ content distribution at the surface in Jiaozhou Bay in September $(\mu \mathrm{g} / \mathrm{L})$.

The $\mathrm{Pb}$ content decreased from the high content of $3.05 \mu \mathrm{g} / \mathrm{L}$ in the center to the surroundings along the gradient, to $0.90 \mu \mathrm{g} / \mathrm{L}$ in the southwestern waters of the bay, to $1.28 \mu \mathrm{g} / \mathrm{L}$ in the central waters of the bay, and to $0.62 \mu \mathrm{g} / \mathrm{L}$ in the northern waters of the bay (Figure 4). 


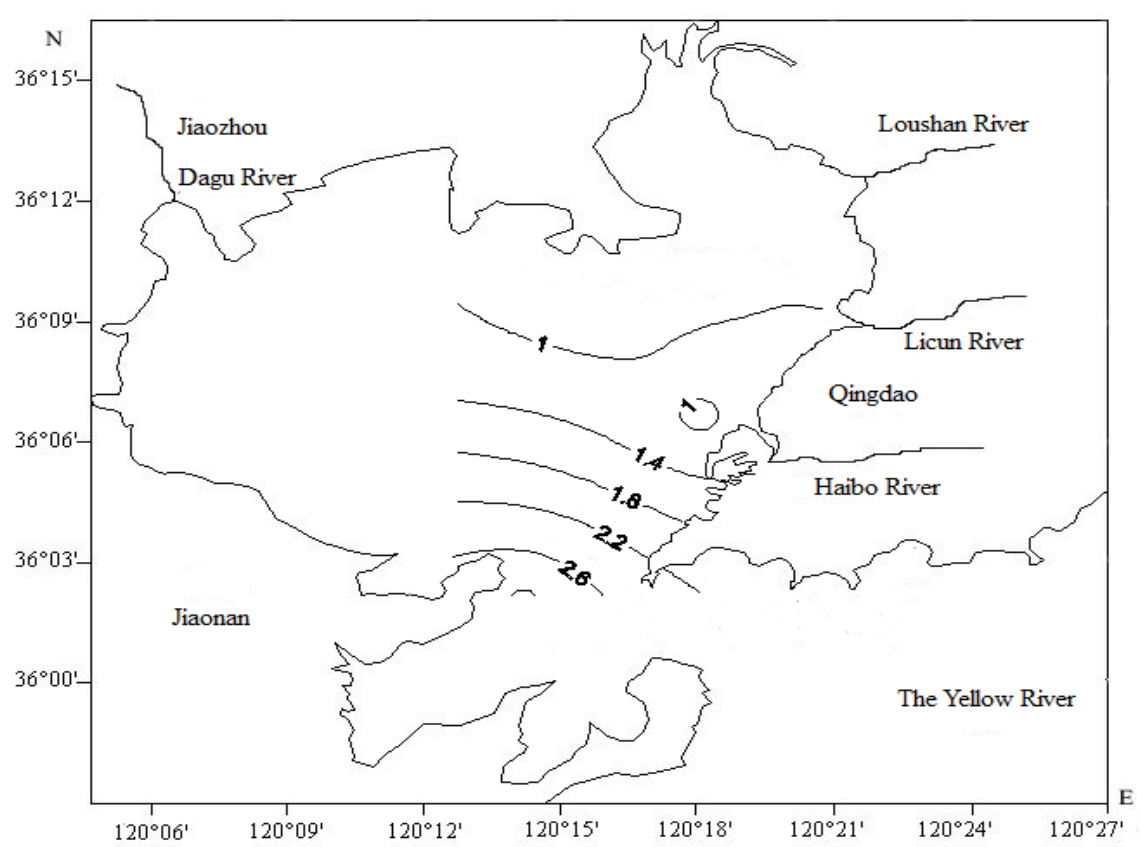

Figure 4. $\mathrm{Pb}$ content distribution at the surface in Jiaozhou Bay in October $(\mu \mathrm{g} / \mathrm{L})$.

\section{Discussion}

\subsection{Water Quality}

In May, September and October, the $\mathrm{Pb}$ content in the waters of Jiaozhou Bay was $0.62-3.05 \mu \mathrm{g} / \mathrm{L}$, which conformed to the national seawater standards of Class I and II. It indicated that in terms of $\mathrm{Pb}$ content, in May, September and October, the entire water body of Jiaozhou Bay was mildly polluted by $\mathrm{Pb}$.

In May, the variation range of $\mathrm{Pb}$ content in the waters of Jiaozhou Bay was $0.84-2.13 \mu \mathrm{g} / \mathrm{L}$, indicating that the water body of Jiaozhou Bay was mildly polluted by $\mathrm{Pb}$. In the estuary of coastal waters of Haibo River, the $\mathrm{Pb}$ content ranged within $2.02-2.13 \mu \mathrm{g} / \mathrm{L}$, which indicated that the water quality in this area achieved the seawater quality standard of Class II and the water was mildly polluted by $\mathrm{Pb}$. In the northern waters and the northeastern waters of Jiaozhou Bay, the $\mathrm{Pb}$ content was relatively low, ranging within $0.84-0.97 \mu \mathrm{g} / \mathrm{L}$. It indicated that in terms of $\mathrm{Pb}$ content, the water quality reached the seawater standard of Class I, so the water did not get any contamination of $\mathrm{Pb}$. In other water areas of Jiaozhou Bay, the $\mathrm{Pb}$ content was relatively high, exceeding the national seawater standard of Class I $(1.00 \mu \mathrm{g} / \mathrm{L})$ but conforming to the national seawater standard of Class II $(5.00 \mu \mathrm{g} / \mathrm{L})$. Therefore, the water was slightly polluted by $\mathrm{Pb}$ content.

In September, the variation range of $\mathrm{Pb}$ content in the waters of Jiaozhou Bay was $0.78-2.74 \mu \mathrm{g} / \mathrm{L}$, indicating that the water body of Jiaozhou Bay was mildly polluted by $\mathrm{Pb}$. In the northern coastal waters and the central waters of Jiaozhou Bay, the $\mathrm{Pb}$ content ranged within $2.05-2.74 \mu \mathrm{g} / \mathrm{L}$, which indicated that the water quality in this area achieved the seawater quality standard of Class II and the water was mildly polluted by $\mathrm{Pb}$. In the eastern waters of the bay, the $\mathrm{Pb}$ content was relatively low, ranging within $0.78-0.84 \mu \mathrm{g} / \mathrm{L}$. It indicated that in terms of 
$\mathrm{Pb}$ content, the water quality reached the seawater standard of Class I, so the water did not get any contamination of $\mathrm{Pb}$. In other water areas of Jiaozhou Bay, the $\mathrm{Pb}$ content was relatively high, exceeding the national seawater standard of Class I $(1.00 \mu \mathrm{g} / \mathrm{L})$ but conforming to the national seawater standard of Class II $(5.00 \mu \mathrm{g} / \mathrm{L})$. Therefore, the water was slightly polluted by $\mathrm{Pb}$ content.

In October, the variation range of $\mathrm{Pb}$ content in the waters of Jiaozhou Bay was $0.62-3.05 \mu \mathrm{g} / \mathrm{L}$, indicating that the water body of Jiaozhou Bay was mildly polluted by $\mathrm{Pb}$. In the mouth waters of the bay, the $\mathrm{Pb}$ content was $3.05 \mu \mathrm{g} / \mathrm{L}$, which indicated that the water quality in this area achieved the seawater quality standard of Class II and the water was mildly polluted by $\mathrm{Pb}$. In the northern waters and northeastern of the bay, the $\mathrm{Pb}$ content ranged within $0.62-0.79$ $\mu \mathrm{g} / \mathrm{L}$. It indicated that in terms of $\mathrm{Pb}$ content, the water quality reached the seawater standard of Class I, so the water did not get any contamination of $\mathrm{Pb}$. In other water areas of Jiaozhou Bay, the $\mathrm{Pb}$ content was relatively high, exceeding the national seawater standard of Class I $(1.00 \mu \mathrm{g} / \mathrm{L})$ but conforming to the national seawater standard of Class II $(5.00 \mu \mathrm{g} / \mathrm{L})$. Therefore, the water was slightly polluted by $\mathrm{Pb}$ content.

\subsection{Sources}

In May, it formed a high $\mathrm{Pb}$ content area in the estuary of coastal waters of Haibo River, which indicated that the $\mathrm{Pb}$ was sourced from the transportation of Haibo River with a relatively high content of $2.13 \mu \mathrm{g} / \mathrm{L}$.

In September, it formed a high $\mathrm{Hg}$ content area in the northern waters of the bay, which indicated that the $\mathrm{Pb}$ was sourced from the transportation of land surface runoff, and the $\mathrm{Pb}$ content was $2.74 \mu \mathrm{g} / \mathrm{L}$.

In October, it formed a high $\mathrm{Hg}$ content area in the mouth waters of the bay, which indicated that the $\mathrm{Pb}$ was sourced from the offshore currents with a relatively high content of $3.05 \mu \mathrm{g} / \mathrm{L}$.

The $\mathrm{Pb}$ content in the waters of Jiaozhou Bay mainly transported from three sources, rivers, surface runoff and offshore currents. The $\mathrm{Pb}$ content transported from rivers was $2.13 \mu \mathrm{g} / \mathrm{L}$, from surface runoff was $2.74 \mu \mathrm{g} / \mathrm{L}$ and from offshore currents was $3.05 \mu \mathrm{g} / \mathrm{L}$.

The $\mathrm{Pb}$ content transported from rivers, surface runoff and offshore currents all exceeded the national seawater standard of Class I $(1.00 \mu \mathrm{g} / \mathrm{L})$ but conformed the national seawater standards of Class II $(5.00 \mu \mathrm{g} / \mathrm{L})$. It indicated that the transportation of rivers, surface runoff and offshore currents had slightly polluted by $\mathrm{Pb}$ content (Table 2). Therefore, the source of $\mathrm{Pb}$ pollution in the waters of Jiaozhou Bay was a non-point pollution source, which mainly came from

Table 2. The surface water quality in Jiaozhou bay in May, September and October.

\begin{tabular}{cccc}
\hline Different Sources & $\begin{array}{c}\text { Transportation } \\
\text { of rivers }\end{array}$ & $\begin{array}{c}\text { Transportation } \\
\text { of surface runoff }\end{array}$ & $\begin{array}{c}\text { Transportation of } \\
\text { offshore currents }\end{array}$ \\
\hline $\mathrm{Pb}$ content/ $\mathrm{\mu g} \cdot \mathrm{L}^{-1}$ & 2.13 & 2.74 & 3.05 \\
\hline
\end{tabular}


the transportation of rivers, the transportation of surface runoff, and the transportation of offshore currents.

\subsection{Transportation Paths of $\mathrm{Pb}$ Content}

The $\mathrm{Pb}$ content mainly had three sources, the transportation of rivers, surface runoff and offshore currents. Thus, human activities took $\mathrm{Pb}$ content to the land and ocean and the $\mathrm{Pb}$ content was transported to the ocean water body through these three paths.

From land, ocean to the water body of Jiaozhou Bay, three different migration paths of $\mathrm{Pb}$ content are shown in the following: 1) Human activities directly discharged $\mathrm{Pb}$ content on land. Through rainwater, the $\mathrm{Pb}$ content transported from surface runoff directly to the water body of Jiaozhou Bay was $2.13 \mu \mathrm{g} / \mathrm{L} .2$ ) Humans discharged $\mathrm{Pb}$ content to land, and then transported the $\mathrm{Pb}$ content to the ocean through rivers. The $\mathrm{Pb}$ content transported by rivers to the water body of Jiaozhou Bay was $2.74 \mu \mathrm{g} / \mathrm{L}$. 3) Humans discharged $\mathrm{Pb}$ content to land and oceans, and then transported $\mathrm{Pb}$ content to the ocean through the above paths. Over time, the accumulation of transported $\mathrm{Pb}$ content in the ocean resulted in an increase in the $\mathrm{Pb}$ content of the ocean. And through the transportation of ocean currents, $\mathrm{Pb}$ content was transported from high content areas to low content areas. The $\mathrm{Pb}$ content of the offshore ocean currents transported to the water body of Jiaozhou Bay was $3.05 \mu \mathrm{g} / \mathrm{L}$. This reveals how the $\mathrm{Pb}$ content from human emissions reached the waters of Jiaozhou Bay through three paths (Figure 5).

The order of $\mathrm{Pb}$ content transported by different paths to the waters of Jiaozhou Bay from large to small is: $\mathrm{Pb}$ content transported by offshore ocean currents $>\mathrm{Pb}$ content transported by surface runoff $>\mathrm{Pb}$ content transported by rivers. Therefore, the $\mathrm{Pb}$ content in the ocean water was very high, and the ocean was slightly polluted by the $\mathrm{Pb}$ content. In terms of $\mathrm{Pb}$ content, the slight pollution of the ocean has aroused human attention.

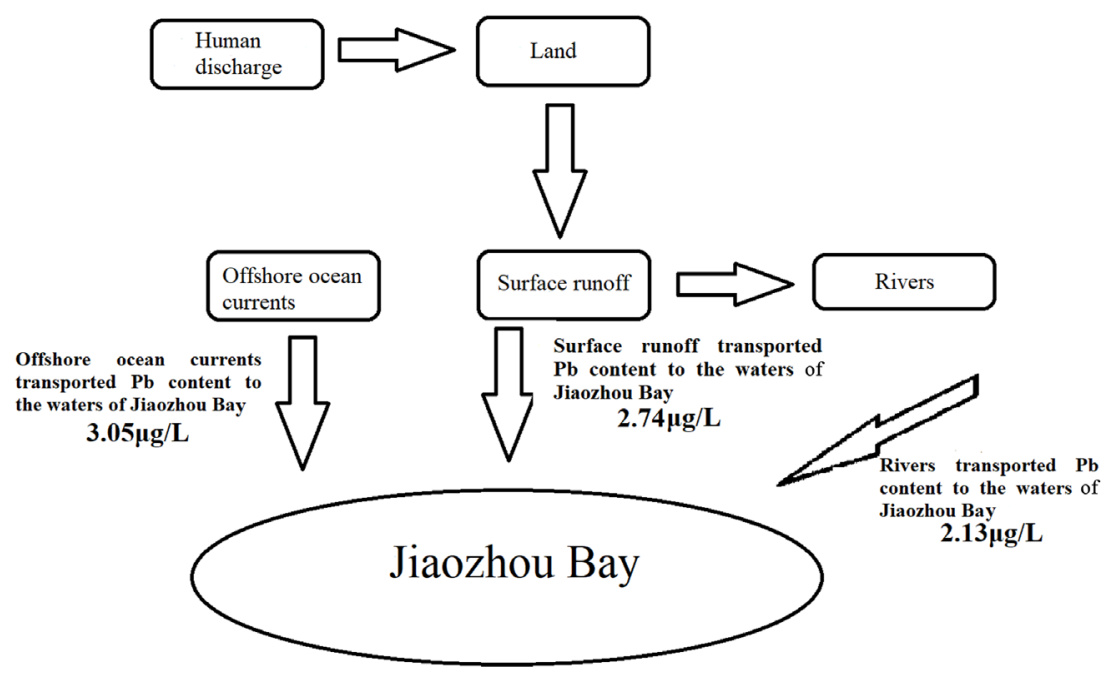

Figure 5. The transportation paths of $\mathrm{Pb}$ content into ocean. 


\subsection{Migration Deposition of $\mathrm{Pb}$ Content}

With the rapid development of industry, humans have discharged a large amount of waste water, waste gas and solid waste containing $\mathrm{Pb}$ into the atmosphere, land and ocean during various activities. The $\mathrm{Pb}$ content in the atmosphere sinks to land and oceans, and then is transported to ocean waters.

In the waters of Jiaozhou Bay, there were three main sources of $\mathrm{Pb}$ content: river transportation, surface runoff transportation and offshore ocean currents transportation, showing three different migration paths for $\mathrm{Pb}$ content. The $\mathrm{Pb}$ content followed the migration paths, revealing the migration and changing process of the $\mathrm{Pb}$ content:

1) The content of $\mathrm{Pb}$ discharged by humans to the land was relatively high, so the content of $\mathrm{Pb}$ transported by surface runoff directly to the ocean through the surface was relatively high, which was $2.74 \mu \mathrm{g} / \mathrm{L}$.

2) The content of $\mathrm{Pb}$ discharged by humans to the land was relatively high. The surface runoff of the land gathered the $\mathrm{Pb}$ content on the land, and then transported the $\mathrm{Pb}$ content to rivers. During the transportation process of rivers, the $\mathrm{Pb}$ content continued to sink, and when the river flowed to the coastal waters of the bay, the $\mathrm{Pb}$ content became relatively low. The content of $\mathrm{Pb}$ transported by rivers to the ocean was relatively low, which was $2.13 \mu \mathrm{g} / \mathrm{L}$.

3) Human activities brought $\mathrm{Pb}$ content to the land and ocean. Through surface runoff and rivers, $\mathrm{Pb}$ content was continuously transported to the ocean. After years of transportation, the $\mathrm{Pb}$ content in the ocean continued to settle and accumulate, resulting in the increase of $\mathrm{Pb}$ content in the ocean. This revealed that the $\mathrm{Pb}$ content of ocean water bodies was very high, and the $\mathrm{Pb}$ content transported by the offshore ocean current was very high, $3.05 \mu \mathrm{g} / \mathrm{L}$ (Figure 5).

With three different migration paths of $\mathrm{Pb}$ content, this paper established a model block diagram of $\mathrm{Pb}$ content along the migration paths, revealing the migration and changing process of $\mathrm{Pb}$ content. In the migration process of $\mathrm{Pb}$ content from different sources, the author discovered the migration rules of $\mathrm{Pb}$ content: 1) As the migration distance increased, the $\mathrm{Pb}$ content continued to decrease. 2) $\mathrm{Pb}$ content continued to accumulate in the ocean, resulting in the high $\mathrm{Pb}$ content in the ocean waters.

\section{Conclusion}

In May, September and October, the $\mathrm{Pb}$ content in the waters of Jiaozhou Bay was $0.62-3.05 \mu \mathrm{g} / \mathrm{L}$, which conformed to the national seawater standards of Class I and II. It indicated that in terms of $\mathrm{Pb}$ content, in May, September and October, the entire water body of Jiaozhou Bay was mildly polluted by $\mathrm{Pb}$.

In May, the variation range of $\mathrm{Pb}$ content in the waters of Jiaozhou Bay was $0.84-2.13 \mu \mathrm{g} / \mathrm{L}$, indicating that the water body of Jiaozhou Bay was mildly polluted by $\mathrm{Pb}$. In the estuary of coastal waters of Haibo River, the $\mathrm{Pb}$ content was relatively high, which indicated that the water was mildly polluted by $\mathrm{Pb}$. In the northern waters and the northeastern waters of Jiaozhou Bay, the Pb content was 
relatively low, indicating that the water did not get any contamination of $\mathrm{Pb}$. In other water areas of Jiaozhou Bay, the $\mathrm{Pb}$ content was relatively high, and the water was slightly polluted by $\mathrm{Pb}$ content.

In September, the variation range of $\mathrm{Pb}$ content in the waters of Jiaozhou Bay was $0.78-2.74 \mu \mathrm{g} / \mathrm{L}$, indicating that the water body of Jiaozhou Bay was mildly polluted by $\mathrm{Pb}$. In the northern coastal waters and central waters of the bay, the $\mathrm{Pb}$ content was relatively high, which indicated that the water was mildly polluted by $\mathrm{Pb}$. In the eastern waters of Jiaozhou Bay, the $\mathrm{Pb}$ content was relatively low, indicating that the water did not get any contamination of $\mathrm{Pb}$. In other water areas of Jiaozhou Bay, the $\mathrm{Pb}$ content was relatively high, and the water was slightly polluted by $\mathrm{Pb}$ content.

In October, the variation range of $\mathrm{Pb}$ content in the waters of Jiaozhou Bay was $0.62-3.05 \mu \mathrm{g} / \mathrm{L}$, indicating that the water body of Jiaozhou Bay was mildly polluted by $\mathrm{Pb}$. In the mouth waters of the bay, the $\mathrm{Pb}$ content was relatively high, which indicated that the water was mildly polluted by $\mathrm{Pb}$. In the northern waters and the northeastern waters of Jiaozhou Bay, the $\mathrm{Pb}$ content was relatively low, indicating that the water did not get any contamination of $\mathrm{Pb}$. In other water areas of Jiaozhou Bay, the $\mathrm{Pb}$ content was relatively high, and the water was slightly polluted by $\mathrm{Pb}$ content.

The $\mathrm{Pb}$ content in Jiaozhou bay mainly had three sources, the transportation of rivers, surface runoff and offshore ocean currents. The $\mathrm{Pb}$ content was 2.13 $\mu \mathrm{g} / \mathrm{L}$ transported from the rivers, $2.74 \mu \mathrm{g} / \mathrm{L}$ from the surface runoff and 3.05 $\mu \mathrm{g} / \mathrm{L}$ from the offshore ocean currents. It demonstrated that the transportation of rivers, surface runoff and offshore ocean currents had been moderated polluted by $\mathrm{Pb}$ content.

From land, ocean to Jiaozhou Bay water bodies, there are three different migration paths of $\mathrm{Pb}$ content: 1 ) The $\mathrm{Pb}$ content transported by surface runoff from land directly to the ocean; 2 ) The $\mathrm{Pb}$ content transported by rivers to the ocean; 3) The $\mathrm{Pb}$ content transported by ocean currents from high content area to low content area. In addition, this article applied model block diagram to reveal the change of $\mathrm{Pb}$ content transported by three paths to the ocean.

The order of $\mathrm{Pb}$ content transported by different paths to the waters of Jiaozhou Bay from large to small is: $\mathrm{Pb}$ content transported by offshore ocean currents $>\mathrm{Pb}$ content transported by surface runoff $>\mathrm{Pb}$ content transported by rivers. Therefore, the $\mathrm{Pb}$ content in the ocean water was very high, and the ocean was slightly polluted by the $\mathrm{Pb}$ content. In terms of $\mathrm{Pb}$ content, the slight pollution of the ocean has aroused human attention.

In the migration process of $\mathrm{Pb}$ content transported from different sources, the author found out the migration rules: 1 ) the $\mathrm{Pb}$ content was continuously decreased with the extension of migration distance; 2 ) the $\mathrm{Pb}$ content in the ocean water body was very high with the accumulation of $\mathrm{Pb}$ content in the ocean.

\section{Acknowledgements}

This research was sponsored by Doctoral Degree Construction Library of Guiz- 
hou Nationalities University and Research Projects of Guizhou Nationalities University ([2014]02), Research Projects of Guizhou Province Ministry of Education (KY [2014] 266), Research Projects of Guizhou Province Ministry of Science and Technology (LH [2014] 7376).

\section{Conflicts of Interest}

The authors declare no conflicts of interest regarding the publication of this paper.

\section{References}

State Oceanic Administration (SOA) (1991). The Specification for Marine Monitoring. Beijing: China Ocean Press.

Yang, D. F., Chen, Y., \& Gao, Z. H. (2005). SiLicon Limitation on Primary Production and Its Destiny in Jiaozhou Bay, China IV Transect Offshore the Coast with Estuaries. Chin. J. OceanoL. LimnoL, 23, 72-90. https://doi.org/10.1007/BF02845147

Yang, D. F., Ge, H. G., Song, F. G., Li, C., \& Yang, B. (2014). The Variation of the Contents of $\mathrm{Pb}$ in Surface Waters in Jiaozhou Bay. Applied Mechanics and Materials, 651653, 1492-1495. https://doi.org/10.4028/www.scientific.net/AMM.651-653.1492

Yang, D. F., Geng, X. Chen, S. T., Xu, Z. J., \& Cui, W. L. (2014). Plumbum Sink and Transfer Process in Jiaozhou Bay. Applied Mechanics and Materials, 651-653, 12161219. https://doi.org/10.4028/www.scientific.net/AMM.651-653.1216

Yang, D. F., Guo, J. H., Zhang, Y. J., Ding, Z. R., \& Bu, Z. G. (2011). Pb Distribution and Sources in Jiaozhou Bay, East China. Journal of Water Resource and Protection, 3, 41-49. https://doi.org/10.4236/jwarp.2011.31005

Yang, D. F., Su, C., \& Gao, Z. H. (2008). Pb Distribution and Translocation in Jiaozhou Bay. Chin. J. Oceanol. Limnol, 26, 296-299.

https://doi.org/10.1007/s00343-008-0296-9

Yang, D. F., Wang, F., \& Gao, Z. H. (2004). Ecological Phenomena of Phytoplankton in Jiaozhou Bay. Marine Science, 28, 71-74.

Yang, D. F., Zhu, S. X., Wang, F. Y., He, H. Z., \& Yang, X. Q. (2014). Distribution and Source of Plumbum in Jiaozhou Bay Waters. Applied Mechanics and Materials, 651653, 1419-1422. https://doi.org/10.4028/www.scientific.net/AMM.651-653.1419

Yang, D. F., Zhu, S.X., Wang, F. Y., Yang, X. Q., \& Wu, Y. J. (2014). Study on the Transport Processes of $\mathrm{Pb}$ in Jiaozhou Bay. Applied Mechanics and Materials, 651-653, 12921294. https://doi.org/10.4028/www.scientific.net/AMM.651-653.1292 